\title{
Introduction: Studying Southern Political Party Activists
}

\author{
John A. Clark and Charles Prysby, Editors
}

The political changes that have occurred in the South over the past several decades have affected the political party organizations in the region. A region once marked by a weak and highly factionalized Democratic Party organization and an almost non-existent Republican Party organization now has two significant party organizations operating in each state. Examining the development of party organizations in the region should tell us much about both political party organizations and southern politics. This study, the Southern Grassroots Party Activists 2001 Project, focuses on political party activists active at the county level. Over 7,000 activists in the eleven southern states were surveyed in 2001. This study is linked to the 1991 Southern Grassroots Party Activists Project, which surveyed a similar group of activists, using a similar questionnaire. The following articles both analyze the 2001 data patterns and compare the 2001 results to the 1991 patterns.

The American Review of Politics has a long tradition of publishing scholarship on southern politics, political parties, and applied politics. This special double issue brings together elements of all three strands of research. The articles that follow draw on a major survey of local party activists in each of the eleven states of the old Confederacy. The authors, experts on parties and politics in their respective states, collected the data using a common survey instrument. The following analyses of the attitudes and behavior of party activists in each state follow a similar outline, allowing us to compare results across states, a task that we take up in the conclusion.

\section{The Political Context: The South}

No region has changed more in recent years than the South. Over the past several decades a competitive two-party system has emerged in a region formerly dominated by the Democrats. From the end of Reconstruction through the middle of the 20th century, Democrats controlled virtually every elected office throughout the region (Key 1949). Republicans began to assert

JOHN A. CLARK is an associate professor of political science at Western Michigan University. CHARLES PRYSBY is a professor of political science at the University of North Carolina at Greensboro. The authors appreciate the contributions that were made by several former students who worked as research assistants during various stages of this project: WMU doctoral student Marcella Myers and former UNCG students Kelly Dunn, Katie McCarthy, and Amanda Osborne worked on the data collection phase of the project. Another former UNCG student, Gabriella Kohlmeier, contributed greatly to the preparation of the manuscripts that appear in these issues. The following articles all rely on data collected by the Southern Grassroots Party Activists 2001 Project, which was supported by National Science Foundation Grant SES-9986501 and SES-9986523, and on data collected by the 1991 SGPA project, which was funded by NSF Grant SES-9009846.

The American Review of Politics, Vol. 24, Spring, 2003: 1-19

(C)2003 The American Review of Politics 
themselves in presidential politics during the 1950s. The 1964 election was a landslide for Democrat Lyndon Johnson nationally, but GOP candidate Barry Goldwater captured all five Deep South states. No Democratic presidential candidate since has 1964 has won the support of a majority of the region's white voters (Black and Black 1987, 269-270). Republican growth below the presidential level occurred at different times in different states. The change generally proceeded by fits and starts, with dramatic advances disappearing in subsequent elections. Over time, however, the solidly Democratic South gave way to a more competitive two-party system. ${ }^{1}$

Much of the growth in competitiveness occurred during the 1970s and 1980 s, but even the 1990s were a decade of substantial change. As late as 1992, Democrats controlled a solid majority of the region's congressional seats. Republicans gained control of both houses of Congress following the 1994 elections, due in large measure to their success in southern elections. The GOP edge in southern U.S. House seats increased from 52 percent elected in 1994 to 57 percent elected in 2000. State legislatures were controlled by the Democrats in every southern state until 1994, but by early 2001 Republicans had won majorities in at least one chamber in six of the eleven states (Bullock and Rozell 2003a).

\section{Party Organizations in the South}

The change in the competitive status of the two major political parties in the South has been accompanied by changes in the nature of the party organizations. A region once marked by a weakly organized and highly factionalized Democratic Party and an almost non-existent Republican Party now has two significant party organizations operating in each of the states. The development of party organizations is both a consequence and a cause of the changes in electoral outcomes discussed above. Understanding the nature of organizational growth will help us to better understand how and why southern politics has changed. Equally important, the lessons can be applied to our understanding of political parties in general, particularly in terms of how party organizations respond to changes in the political milieu within which they operate. The South presents us with an excellent case study of party organizations operating in an environment of partisan change.

It is widely accepted among those who study them that political parties are essential for the functioning of modern representative democracy. Yet despite their importance for the political system, American political parties have often been accused of lacking the health, vitality, and strength needed to make the democratic process function as well as we might desire. Over the past few decades, many observers and scholars have reported on the decline of political parties in the United States. At the same time, however, other scholars have argued that the "decline of party" thesis is greatly 
exaggerated. While parties are weaker is some ways, such as in the number of voters who are strong identifiers or in the ability of party leaders to control the presidential nomination process, parties are clearly stronger in other ways (for a recent summary of these trends, see Cohen, Fleisher, and Kantor 2001). The party organizations at the national level are better financed and better staffed than they were two or three decades ago (Herrnson 1994; Kayden and Mahe 1985). The same can be said of the headquarters of many of the state parties as well (Bibby 1990; Cotter et al. 1984; Gibson et al. 1983). As uncertainty over electoral outcomes increases due to a decline in partisanship or an increase in competition, political leaders turn to party organizations as a way to increase their chances of winning elections (Schlesinger 1985; Herrnson and Menefee-Libey 1990; Klinkner 1994; Aldrich 1995).

There was little need for parties to organize in the Democratic "Solid South" described by V.O. Key (1949). In fact, factional leaders often feared that too much organizational infrastructure would give an unfair advantage to one group or the other. Once a foothold of two-party competition was established, party organizations became a way to recruit candidates and mobilize voters. Republicans pioneered the strategy of "top-down" organizational development by pumping money and other resources from the national party to the states and below, and Democrats quickly followed suit (Herrnson 1994; Wekkin 1985). The emphasis on building organizations in the 1970s and 1980s paved the way for the highly competitive nature of southern politics that we see today.

\section{Grassroots Activists: Manning the Front Lines of Politics}

While considerable scholarly attention has been focused on the strengthening of the national and state party organizations, less attention has been given to local parties. While perhaps less visible than the state or national organizations, county party organizations are not irrelevant, even in today's candidate centered and media oriented political world (Frendreis and Gitelson 1993). The grassroots activists in the county parties are spokespersons for the party in the community, likely volunteers for and contributors to campaign efforts, and even potential candidates for office. Along with local office holders, the grassroots activists in the party help to define the image that the local party has in the community (Coleman 1996).

As soldiers on the front lines of politics, local party activists provide a linkage between the general public and higher strata of political elites. The barriers to involvement that they face are relatively low compared to other forms of political participation. Through the activities they perform, local party officials mobilize voters, recruit candidates, and maintain an organizational presence between elections. 


\section{The Southern Grassroots Party Activists 2001 Project}

This study, the Southern Grassroots Party Activists 2001 Project, focuses on grassroots political party activists in the South, defined as the eleven states of the old Confederacy. ${ }^{2}$ Our study is a follow up to the original SGPA study, coordinated by Charles Hadley and Lewis Bowman and conducted in $1991 .^{3}$ The goal of both SGPA studies was to analyze the attitudes and behavior of southern grassroots party activists, generally defined as county chairs and other members of the county executive committees.

The 2001 SGPA study surveyed over 7,000 party activists. The details of the sampling plan for each state and a summary of response rates by state and party are in the appendix to this article. In most cases, three waves of questionnaires were mailed out in an effort to maximize the response rate, which exceeded 50 percent overall, although there was substantial variation from state to state and even from one party to the other within a given state. The sample for the original SGPA study was similar to the one for the current study; a full description of that sample can be found in Hadley and Bowman (1995, 211-214).

The 2001 SGPA study asked respondents about a variety of attitudes and behavior, including their reasons for becoming and staying involved in party politics, their attitudes toward party activity, their involvement in campaign activities and in party organizational activities, their orientations on issues of public policy, and their social and demographic characteristics. Many of the questions employed in the 2001 study were also used in the 1991 study, providing an opportunity to study change in attitudes and behavior over time. Other questions asked in 2001 were not asked in 1991, so it is not possible to examine change over time for all items. A copy of the 2001 questionnaire is in the appendix to this article.

In the articles that follow, the state investigators for the 2001 SGPA study analyze the current condition of grassroots parties in their states. Each article follows the same basic format. First, trends in electoral politics and state party organizational development are examined. These trends help set the context for local party organizations in each state. Next, the authors use the survey of grassroots activists to explore changes in local parties across the decade of the 1990s. Particular attention is focused on the demographic makeup of the activists, their attitudes about politics and public policy, and the activities they carry out on behalf of their organizations. The patterns the authors uncover are not the same in every state. In general, however, their findings indicate that the parties are becoming more diverse demographically (especially the Democrats) and increasingly polarized ideologically. In a region where local parties were once barely visible (Key 1949), today's grassroots activists are conducting a wide range of activities. 


\title{
APPENDIX SGPA 2001: Description of the Sampling Plan and Response Rates
}

The SGPA 2001 project aimed at surveying county-level political party activists from both the Democratic and Republican parties in each of the eleven southern states. The target population varied somewhat from state to state and even between parties in the same state, due to differences in party organization and differences in the availability of names. In every case, the intent was to interview county chairs and other members of the county executive committees. The sampling plan for each state and party is described below. The number of individuals initially selected, the number of valid addresses, and the number of returned questionnaires for each state are all provided in the table at the end of this description.

\begin{abstract}
Alabama
Democrats: The sample included all 67 county chairs, as well as county committee members from 41 of the 67 counties. These were the 41 counties that provided lists of county committee members and they included all of the state's largest counties. The lists were provided by the county chairs and included 1,241 county committee members. From these, a systematic random sample of 926 individuals was selected. The final sampling list included the 67 county chairs plus the 926 county committee members.

Republicans: The sample included all 67 county chairs, as well as county committee members from 31 of the 67 counties, all of which were asked to provide lists. A list of all state Republican party executive committee members was also obtained, all of which were shown to also be members of the county committee, and this list was merged with the 31 county lists. The merged list contained 922 county committee members. The final sampling list included the 67 county chairs plus the 922 county committee members.
\end{abstract}

\section{Arkansas}

Democrats: The sample was drawn from the list of all county chairs and all county committee members for each of the 75 counties. The size of the county committees differs dramatically from county-to-county. These names and addresses were provided by the state party headquarters. For each county, the proportionate number of individuals were randomly drawn from the committee to develop an overall sample size of 711 for the state.

Republicans: The sample was drawn from county chairs, as well as including all state Republican committee members, county Republican Women chairs, and College Republican chairs (all of whom also serve as county committee members). The names and addresses were provided by the state party headquarters. The list included 291 names.

\section{Florida}

Democrats: The sample included all county chairs for each of the 67 counties. At the time of mailing the questionnaires, 9 counties had a vacant chair. The Florida Democratic Party did not have a central listing of members of executive committee members for each county. Consequently, requests were made for a list of members from each county chair. This information was provided by 38 counties. An initial respondent list of 800 committee members and chairs was drawn. Given the concentration of Florida's population in seven urban counties, 300 names were taken from Broward, Dade, Duval, Hillsborough, Leon, and Orange counties (Pinellas county was missing), and the remaining 500 from all the other counties. 
6 | John A. Clark and Charles Prysby, Editors

Appendix (continued)

Republicans: The sample included all county chairs and state committee members for each of the 67 counties. At the time of mailing the questionnaires, 6 counties had a vacant chair, and 9 state committee positions were also vacant. The Republican Party of Florida chose not to release their listing of members of executive committee members for each county. Consequently, requests were made for a list of members from each county chair. This information was provided by 44 counties. An initial respondent list of 800 committee members and chairs was drawn. Given the concentration of Florida's population in seven urban counties, 300 names were taken from Broward, Dade, Duval, Hillsborough, and Orange counties (Leon and Pinellas counties were missing), and the remaining 500 from all the other counties.

\section{Georgia}

Democrats: The sample included county chairs only. The lists of county chairs were obtained through the office of the executive director of the state Democratic party. Attempts were made to obtain the names and addresses of other grassroots activists, such as precinct chairs, but these efforts were unsuccessful. As a result, the sample was limited to the county chairs.

Republicans: The sample included county chairs and other activists. The lists of county chairs were obtained through the web site of the state Republican Party. In addition to the 191 county chairs or co-chairs, a list of 134 other activists was obtained. The final sample included both groups.

\section{Louisiana}

Democrats: The sample included all members of the Democratic Parish Executive Committees from Louisiana's 64 parishes. These officials were elected on March 14, 2000 and serve for four-year terms. The Louisiana Secretary of State's Office provided names and addresses of these committee members. The chair of each parish executive committee is elected from among the membership of the committee following the election. The state Democratic Party supplied a partial list of chairs that was completed by telephone calls placed to respondents from the missing parishes.

Republicans: The sample included all members of the Republican Parish Executive Committees from Louisiana's 64 parishes. These officials were elected on March 14, 2000 and serve for four-year terms. The Louisiana Secretary of State's Office provided names and addresses of these committee members. The chair of each parish executive committee is elected from among the membership of the committee following the election. A listing of the chairs was provided by the state Republican Party.

\section{Mississippi}

Democrats: The sample included all county chairs and all county executive committee members from counties where we were able to obtain lists. Fifteen of the state's 82 counties did not have a current chair according to state party records, and despite repeated contacts with the state party and with each county chair, lists of county executive members were not obtained from 37 of the 82 counties. The sample thus consisted of 67 county chairs and 1072 executive committee members from 45 counties. This sample appears representative of Democratic activists in the state as a whole. Using the 1991 Mississippi Democratic sample from the first NSF Grassroots Party Activists project, differences in such key factors as education level, factionalism amount, ideological selfidentification, race, sex, and state campaign activity between sampled counties and those 
not sampled were minute and consistently lacked statistical significance.

Republicans: The sample included all county chairs, as well as a representative sample of all county executive committee members. These lists were comprehensive and were obtained from the state party headquarters. Five of the state's 82 counties did not have a current chair according to their records. The total number of county executive committee members in the state is 1,257 , from which a random sample of 981 was chosen, so each member had a .78 chance of inclusion in the sample. All 77 county chairs were sent questionnaires, as was this sample of 981 county executive committee members.

\section{North Carolina}

Democrats: The sample included all county chairs and other elected county executive committee members for each of the 100 counties. In addition to the county chair, there are five other elected members of the county executive committee-three vicechairs, a secretary, and a treasurer. However, not all of these positions were filled for each county, so there were considerably fewer than 600 elected members of the county executive committees (508 names, 483 names with valid addresses). These names were provided by the state party headquarters. This list was supplemented by a sample of precinct chairs from the seven counties containing a major city (212 names, 207 valid addresses). These names were obtained by contacting the county chairs in these seven counties. The addition of the precinct chairs from the urban counties provides additional respondents from the most populous counties and makes the proportion of respondents from these counties roughly proportional to their share of the population of the state.

Republicans: The sampling included all county chairs and other elected county executive committee members for each of the 100 counties. In addition to the county chair, there are three other elected members of the county executive committee-a vicechair, a secretary, and a treasurer. However, not all of these positions were filled for each county, so there were somewhat fewer than 400 elected members of the county executive committees (370 names, 351 names with valid addresses). These names were provided by the state party headquarters. As with the Democrats, this list was supplemented by a sample of precinct chairs from the counties containing a major city (146 names, 144 valid addresses). However, two of these seven counties, Mecklenburg (Charlotte) and Forsyth (Winston-Salem), did not supply a list of precinct chairs, so these two counties are represented in the sample only by the elected members of the county executive committee. As with the Democrats, the addition of the precinct chairs from the urban counties provides additional respondents from the most populous counties and makes the proportion of respondents from these counties roughly proportional to their share of the population of the state.

\section{South Carolina}

Democrats: The sample included all county chairs and randomly selected precinct presidents and county executive committee members from each organized precinct in the state. These lists were provided by the state party headquarters. A number of counties were not included in the state lists, so the county chairs in those counties were contacted to request their precinct organizational lists. Precinct lists from nine counties were not obtained either because the county had not organized at the precinct level in the past three years or because they simply did not have the precinct lists available (or would not make them available; it is not entirely clear in all cases). Moreover, any response which indicated that the respondent was not a precinct official in spite of being listed as such on the party records was excluded from the sample. Unfortunately, two major urban counties, 


\section{Appendix (continued)}

Spartanburg and Richland counties, are under-represented in the sample because neither county provided precinct organizational lists. The lists from the state party headquarters included a handful of precinct officials from each of these counties, but they were clearly incomplete.

Republicans: The sample included all county chairs and randomly selected precinct presidents and county executive committee members from each organized precinct in the state. These lists were provided by the state party headquarters. As with the Democrats, not all counties were organized at the precinct level, so the sample did not include all 46 counties (except for the county chairs). Moreover, as with the Democrats, any response which indicated that the respondent was not a precinct official in spite of being listed as such on the party records was excluded from the sample.

\section{Tennessee}

Democrats: The sample included all members of the executive committees of each of the 95 counties in Tennessee, including party chairs in each county. The number of members on executive committees varied considerably from county to county, much more so than among Republicans. The state Democratic Party provided names and addresses for 780 county party leaders.

Republicans: The sample included all members of the executive committees of each of the 95 counties in Tennessee, including party chairs in each county. The number of seats on these committees was much more uniform across counties than among Democrats. The state Republican Party headquarters provided names and addresses for 439 county party leaders.

\section{Texas}

Democrats: The sample included all 251 county chairs (three others were vacant), as well as county precinct chairs (who also serve on the county committees). Inasmuch as the state committee had not finished compiling their statewide list at the time that sampling began, lists supplied by county chairs, either by mail or reference to web sites, were relied upon. This resulted in a precinct activist sample drawn from two large metropolitan counties (Harris and Dallas), two from suburban counties (Collin and Denton), one rural county (Grayson), and one isolated but metropolitan North Texas county (Wichita). The addition of the precinct chairs provided respondents from the most populous counties, making the proportion of respondents roughly proportional to their share of the population of the state.

Republicans: The sample included 252 people classified as county chairs by the State Republican Committee. However, this includes seven people who also served as chairs of state senatorial districts in Harris County (Houston). Hence, Republicans have a single chair in 245 of the 254 counties. Despite repeated attempts and assurances, the Texas Republican Committee would not supply a list of precinct activists, as it is not their practice to endorse such activities. Consequently, the state chair would not provide a letter of endorsement, and the GOP sample was increased slightly, (mistakenly) anticipating a lower response without the endorsement. Hence, the sample relied on lists supplied by county chairs by either mail or reference to Web sites. This resulted in a precinct activist sample drawn from two large metropolitan counties (Harris and Dallas), two from suburban counties (Collin and McClennan), one rural county (Parker), and two isolated but metropolitan North Texas counties (Lubbock and Wichita). As with the Democrats, 
the addition of the precinct chairs provided respondents from the most populous counties and made the proportion of respondents roughly proportional to their share of the population of the state.

\section{Virginia}

Democrats: The sample included 500 randomly selected party activists, including central committee members, chairs and county/city committee members. The sample was drawn from city or county chairs, central committee members, and county or city committee members, as Virginia's parties are not officially organized to the precinct level. The respondents were obtained from a list provided by the state Democratic Party.

Republicans: The sample included 225 committee members provided by local chairs. Despite lack of assistance from the Executive Director of the Virginia Republican Party, lists were obtained of the central committee membership and local committee chairs. As with the Democrats, the sample was drawn from city or county chairs, central committee members, and county or city committee members, as Virginia's parties are not officially organized to the precinct level. Many included in the sample had given prior agreement to participate, resulting in a much higher response rate.

\section{Summary of Response Rates}

\begin{tabular}{llrrrrr}
\hline State & Party & $\begin{array}{c}\text { Initial } \\
\text { List }\end{array}$ & $\begin{array}{c}\text { Bad } \\
\text { Addresses }\end{array}$ & $\begin{array}{c}\text { Valid } \\
\text { Addresses }\end{array}$ & $\begin{array}{c}\text { Completed } \\
\text { Questionnaires }\end{array}$ & $\begin{array}{c}\text { Response } \\
\text { Rate (\%) }\end{array}$ \\
\hline AL & Dem & 993 & 66 & 927 & 403 & 43.5 \\
& Rep & 989 & 68 & 921 & 451 & 49.0 \\
AR & Dem & 711 & 49 & 662 & 381 & 57.6 \\
& Rep & 291 & 18 & 273 & 150 & 54.9 \\
FL & Dem & 800 & 62 & 738 & 296 & 40.1 \\
& Rep & 800 & 71 & 729 & 306 & 42.0 \\
GA & Dem & 137 & 3 & 134 & 73 & 54.5 \\
& Rep & 346 & 21 & 325 & 183 & 56.3 \\
LA & Dem & 449 & 8 & 441 & 257 & 58.3 \\
& Rep & 384 & 12 & 372 & 244 & 65.6 \\
MS & Dem & 1,139 & 103 & 1,036 & 369 & 35.6 \\
& Rep & 1,058 & 80 & 978 & 462 & 47.2 \\
NC & Dem & 720 & 30 & 690 & 417 & 60.4 \\
& Rep & 516 & 21 & 495 & 306 & 61.8 \\
SC & Dem & 867 & 40 & 809 & 401 & 49.6 \\
& Rep & 855 & 34 & 806 & 404 & 50.1 \\
TN & Dem & 780 & 99 & 681 & 316 & 46.4 \\
& Rep & 439 & 14 & 425 & 247 & 58.1 \\
TX & Dem & 890 & 16 & 874 & 550 & 62.9 \\
& Rep & 1,100 & 38 & 1,072 & 686 & 64.0 \\
VA & Dem & 500 & 113 & 387 & 150 & 38.8 \\
& Rep & 225 & 41 & 184 & 118 & 64.1 \\
Total & Dem & & & 7,379 & 3,613 & 49.0 \\
& Rep & & 6,580 & 3,557 & 54.0 \\
All & & & & 13,959 & 7,170 & 51.4 \\
\hline \multirow{4}{*}{ Tem } & & & & &
\end{tabular}


Appendix (continued): Questionnaire

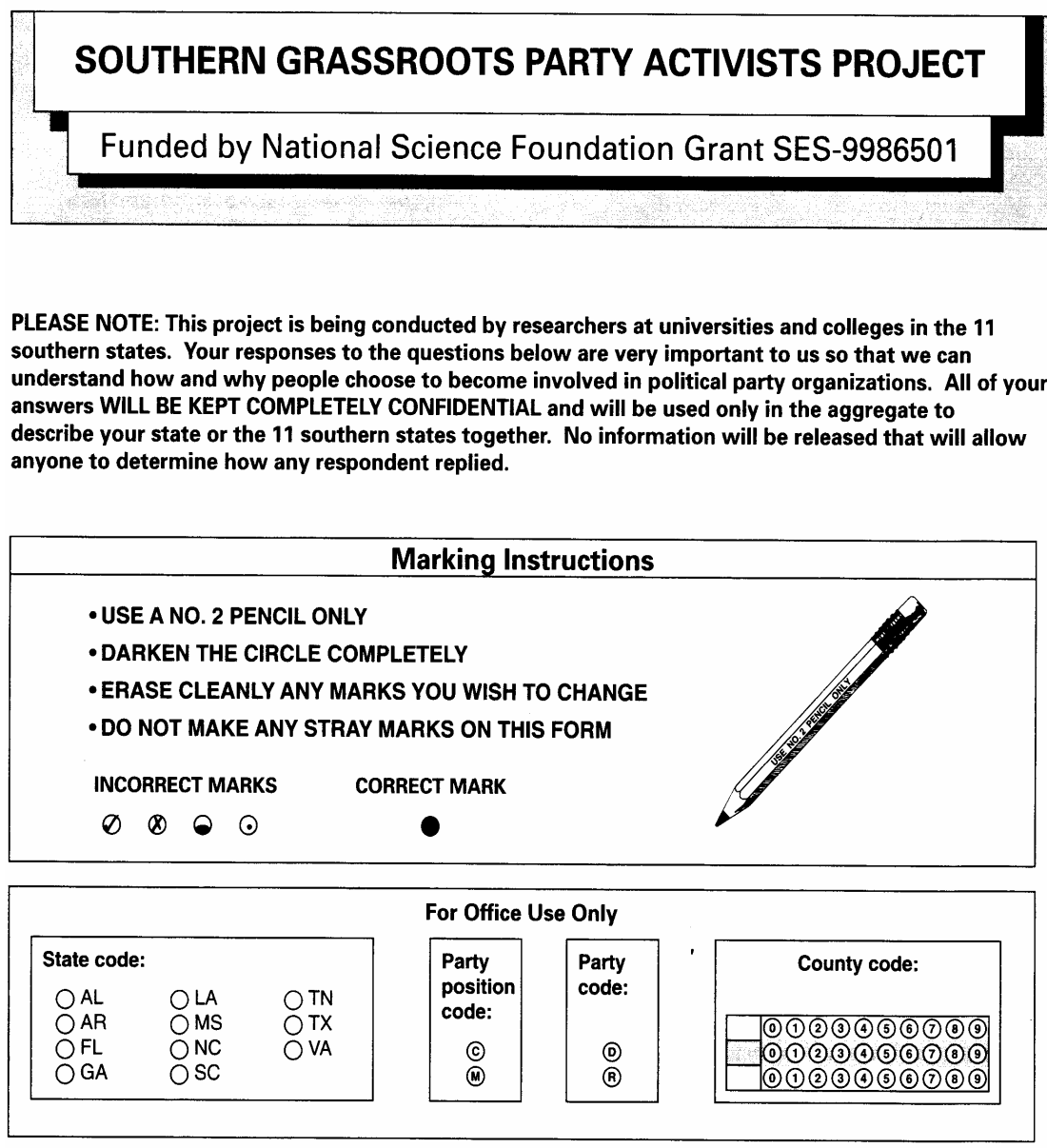

1. First, a few questions about your party position.

1a. In what year did you occupy your current party position?

(Mark the last two digits of the year; e.g. mark 98 for 1998)

\begin{tabular}{|c|c|}
\hline & Year \\
\hline 19 & $\begin{array}{l}\text { (0) (1) (2) (3) (4) (5) (6) (7) (8) (9) } \\
\text { (0) (1) (2) (3) (4) (5) (6) (7) (8) (9) }\end{array}$ \\
\hline
\end{tabular}

$1 b$.

When did you first become active in politics; that is, in doing more than merely voting?

Year

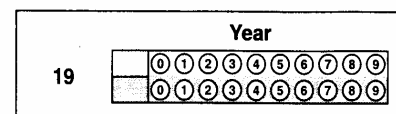

PLEASE DO NOT WRITE IN THIS AREA

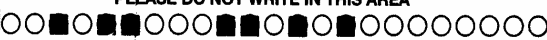


2. Next, we would like to ask you about how you became involved in party politics.

2a. Please indicate what role each of the following played in your decision to seek your current party position. Was it a major or minor consideration?

1) Urged to run by party official

2) Urged to run by elected official

3) Urged to run by candidate for elected office

4) Urged to run by friends or family

members active in the party

5) Decided to run pretty much on my own

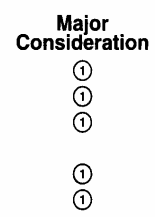

Minor

Consideration

Not a
Consideration

deration

(2)

(2)

(3)

(3)

(2)

(2) (3)

(2)

(3)

2b. Please indicate what role each of the following played in your decision to first become involved in party politics

1) Urged to participate by party official

2) Urged to participate by elected official

3) Urged to participate by candidate for elected office

4) Urged to participate by friends or family members active in the party

5) Decided to participate pretty much on my own

$\begin{array}{ccc}\begin{array}{c}\text { Major } \\ \text { Consideration }\end{array} & \begin{array}{c}\text { Minor } \\ \text { Consideration }\end{array} & \begin{array}{c}\text { Not a } \\ \text { Consideration }\end{array} \\ \text { (1) } & \text { (2) } & \text { (3) } \\ \text { (1) } & \text { (2) } & \text { (3) } \\ \text { (1) } & \text { (2) } & \text { (3) } \\ \text { (1) } & \text { (2) } & \text { (2) }\end{array}$

2c. Rate each of the following in terms of its importance in your personal decision to seek your current party position.

1) Friendship with a candidate

2) Friendship with a political party official

3) Political work is part of my way of life

4) I am strongly attached to my political party

5) I enjoy the friendship and social contact I have with other party workers

6) My family's involvement in party politics

7) I like the fun and excitement of campaigns

8) I am trying to build a personal position in politics

9) I see campaign work as a way to influence politics and government

10) I see working in the political party generally as a way to influence politics and government

11) I like the feeling of being close to people who are doing important things

12) Party work helps me make business contacts

13) Party work helps me fulfill my sense of

community obligation

14) Party work gives me a feeling of recognition in

the community

15) My concern with public issues

16) To support candidates whom I believe in

\begin{tabular}{|c|c|c|c|}
\hline $\begin{array}{l}\text { Very } \\
\text { Important } \\
\text { (1) } \\
\text { (1) } \\
\text { (1) } \\
\text { (1) }\end{array}$ & $\begin{array}{c}\text { Somewhat } \\
\text { Important } \\
\text { (2) } \\
\text { (2) } \\
\text { (2) } \\
\text { (2) }\end{array}$ & $\begin{array}{c}\text { Not Very } \\
\text { Important } \\
\text { (3) } \\
\text { (3) } \\
\text { (3) } \\
\text { (3) }\end{array}$ & $\begin{array}{c}\text { Not } \\
\text { Important } \\
\text { At All } \\
\text { (4) } \\
\text { (4) } \\
\text { (4) } \\
\text { (4) }\end{array}$ \\
\hline $\begin{array}{l}\text { (1) } \\
\text { (1) } \\
\text { (1) }\end{array}$ & $\begin{array}{l}\text { (2) } \\
\text { (2) } \\
\text { (2) }\end{array}$ & $\begin{array}{l}\text { (3) } \\
\text { (3) } \\
\text { (3) }\end{array}$ & $\begin{array}{l}\text { (4) } \\
\text { (4) }\end{array}$ \\
\hline (1) & (2) & (3) & (4) \\
\hline (1) & (2) & (3) & (4) \\
\hline (1) & (2) & (3) & (4) \\
\hline (1) & $\begin{array}{l}\text { (2) } \\
\text { (2) }\end{array}$ & (3) & (4) \\
\hline (1) & (2) & (3) & (4) \\
\hline $\begin{array}{l}\text { (1) } \\
\text { (1) } \\
\text { (1) }\end{array}$ & $\begin{array}{l}\text { (2) } \\
\text { (2) } \\
\text { (2) }\end{array}$ & $\begin{array}{l}\text { (3) } \\
\text { (3) } \\
\text { (3) }\end{array}$ & $\begin{array}{l}\text { (4) } \\
\text { (4) } \\
\text { (4) }\end{array}$ \\
\hline
\end{tabular}


Appendix (continued)

3. Party workers often mention the following activities as being an important part of their job. In your current party position which of these activities are among the important things you do?

1) Contacting voters

2) Raising money

3) Getting people to register to vote

4) Campaigning

5) Public relations

6) Contacting new voters

7) Participating in party meetings and business

8) Recruiting and organizing workers

9) County party organizational work

10) Increasing political information for others

11) Policy formulation

12) Getting candidates for local office

13) Other nominating activities

14) Helping to develop a party Web site

4. Next, we would like to ask you about your interest and affiliations in politics.

4a. Before your current party position, have you held any of the following?

1) Another party position? (1) Yes (2) No

2) An appointed public office? (1) Yes (2) No

If "yes", how many other party or appointed positions have you held? (Please mark)

$\bigcirc 01 \bigcirc 02 \quad \bigcirc 03 \quad \bigcirc 04 \quad \bigcirc 05+$

4b. Have you ever held an elected public office? (1) Yes (2) No

4c. Have you ever run unsuccessfully for elected public office?

(1) Yes (2) No

4d. Do you expect to run for public office in the future?

(1) Yes (2) No (3) Not sure

4e. Have your parents or other relatives ever been active in politics beyond merely voting? OYes $O$ No

4f. How would you describe your parents' party affiliation at the time you were growing up?

Father's party: Mother's party:

(1) Democrat

(2) Republican

(3) Independent

(4) Other

(1) Democrat

(2) Republican

(3) Independent

(5) Do not know

(4) Other

(5) Do not know

$\begin{array}{cc}\begin{array}{c}\text { Very } \\ \text { Important }\end{array} & \begin{array}{c}\text { Somewhat } \\ \text { Important }\end{array} \\ \text { (1) } & \text { (2) } \\ \text { (1) } & \text { (2) } \\ \text { 1) } & \text { (2) } \\ \text { (1) } & \text { (2) } \\ \text { (1) } & \text { (2) } \\ \text { (1) } & \text { (2) } \\ \text { (1) } & \text { (2) } \\ \text { (1) } & \text { (2) } \\ \text { (1) } & \text { (2) } \\ \text { 1) } & \text { (2) } \\ \text { (1) } & \text { (2) } \\ \text { (1) } & \text { (2) } \\ \text { (1) } & \text { (2) } \\ \text { (1) } & \text { (2) }\end{array}$

Not Not

Not

Very Important

(3)

4g. How would you describe your own political party affiliation: In state politics? In national politics?

State politics: National politics:

(1) Strong Democrat (1) Strong Democrat (2) Weak Democrat (2) Weak Democrat

(3) Ind. but lean Democratic (3) Ind. but lean Democratic a

(4) Independent (4) Independent

(5) Ind. but lean Republican (5) Ind. but lean Republican

(6) Weak Republican (6) Weak Republican

(7) Strong Republican (7) Strong Republican

4h. In the 1996 election for president, how did you vote?
(1) Voted for Clinton
(2) Voted for Dole
(4) Voted for another
$\begin{array}{ll}\text { (3) Voted for Perot } & \text { (5) Did not vote }\end{array}$
candidate

4i. In the $\mathbf{2 0 0 0}$ election for president, how did you vote?

(1) Voted for Bush $\quad$ (3) Voted for another

(2) Voted for Gore candidate

(4) Did not vote

4j. Have you ever voted for a minor party or independent candidate for any office in the pas ten years?

OYes O no

PLEASE DO NOT WRITE IN THIS AREA

Joonongooonaodono0000000

Page 3 
5. How important would you say being a member of the county party organization is to you personally?

(1) Very important

(2) Somewhat important

(3) Not very important

(4) Not important at all

6. Have you ever been affiliated with a different political party?

(1) Yes

(2) No (IF "No", SKIP TO QUESTION 7.)

$\rightarrow$ 6a. If "Yes", which political party?

(1) Democrats

(2) Republicans

(3) Reform

(4) Other

6b. If you have switched political parties, in what year did you switch? (mark the last two digits of the year; e.g., mark 95 for 1995)

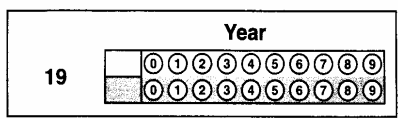

6c. Which of the following were important or not important in your decision to switch parties?

Please mark each question.

1) The party to which I switched had better, more appealing candidates

2) The party to which I switched was much more likely to take the right stand on issues

3) I switched parties because friends, relatives, or fellow workers persuaded me to do so

4) The party to which I switched offered greater opportunities for personal advancement (political career, business contacts, etc.)

5) The party to which I switched is more active and has a superior organization

$\begin{array}{cc}\text { Important } & \begin{array}{c}\text { Not } \\ \text { Important }\end{array} \\ 0 & 0 \\ 0 & 0 \\ 0 & 0 \\ 0 & 0 \\ 0 & 0\end{array}$

6d. Which ONE of the above reasons (1-5 in Question 6c) was MOST IMPORTANT in your decision to switch parties?

(1)(2)(3)(4) (5)

7. Candidates, party workers, and party organizations emphasize different campaign activities. Which of the following activities did you do in recent election campaigns? Please mark all activities that you did:

(A) Organized door-to-door canvassing

(B) Organized campaign events (rallies, forums, etc.)

(C) Arranged fund-raising activities

(2) Sent mailings to voters

() Distributed campaign literature

(†) Organized telephone campaigns

(G) Purchased billboard space

(i) Distributed posters or lawn signs

(1) Contributed money to campaigns

(J) Conducted voter registration drives

®) Utilized public opinion surveys

(L) Dealt with campaign media (press releases, radio/TV, etc.)

(ii) Helped to construct or maintain a campaign Web site 
Appendix (continued)

8. We have found that party officials do not always work as actively during elections at one level as they do during elections at other levels. What about you? How actively do you work:
8a. In local elections?
8b. In state elections?
8c. In national elections?

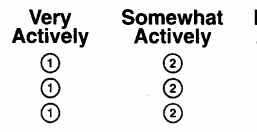

Not Very Actively
Actively

9a. Have any candidates talked with you about running for office before they announced their candidacy?

(1) Yes (2) No

9b. Have you ever suggested to someone that they ought to run for public office?

(1) Yes (2) No

10. Please indicate whether you agree or disagree with the following statements.

10a. Good party workers support any candidate nominated by the party even if they basically disagree with the candidate

10b. Party organization and unity are more important than free and total discussion of issues which may divide the party

10c. A political party should be more concerned with issues than with winning elections

10d. Controversial positions should be avoided in party platform to insure party unity

10e. Broad electoral appeal is more important than a consistent ideology

10f. Good party workers should remain officially and unofficially neutral in primary contests even when they have a personal preference Strongly

Agree

Disagree $\quad \begin{gathered}\text { Strongly } \\ \text { Disagre }\end{gathered}$

\begin{tabular}{|c|c|c|c|}
\hline (1) & (2) & (3) & (4) \\
\hline (1) & (2) & (3) & (4) \\
\hline (1) & (2) & (3) & (4) \\
\hline (1) & (2) & (3) & (4) \\
\hline (1) & (2) & (3) & (4) \\
\hline (1) & (2) & (3) & (4) \\
\hline
\end{tabular}

11. Now we would like to ask you about your communication in the party organization. How often do you communicate with:

11a. County party chair

11b. Other county party committee members

11b. Other county party

11c. State party chair

11e. National committee members

11f. Local government officials

11g. State government officials

11h. National government officials

$\begin{array}{ccccc}\text { Very Often } & \text { Often } & \text { Seldom } & \text { Never }= \\ \text { (1) } & \text { (2) } & \text { (3) } & \text { (4) } & = \\ \text { (1) } & \text { (2) } & \text { (3) } & \text { (4) } & = \\ \text { (1) } & \text { (2) } & \text { (3) } & \text { (4) } & = \\ \text { (1) } & \text { (2) } & \text { (3) } & \text { (4) } & = \\ \text { (1) } & \text { (2) } & \text { (3) } & \text { (4) } & = \\ \text { (1) } & \text { (2) } & \text { (3) } & \text { (4) } & = \\ \text { (1) } & \text { (2) } & \text { (3) } & 4 & = \\ \text { (1) } & \text { (2) } & \text { (3) } & \text { (4) } & =\end{array}$

12. What about your political beliefs? Do you consider yourself:

(1) Very liberal

(2) Somewhat liberal

(3) Middle of the road/moderate

(4) Somewhat conservative

(5) Very conservative 
13. What are your views concerning the following issues?

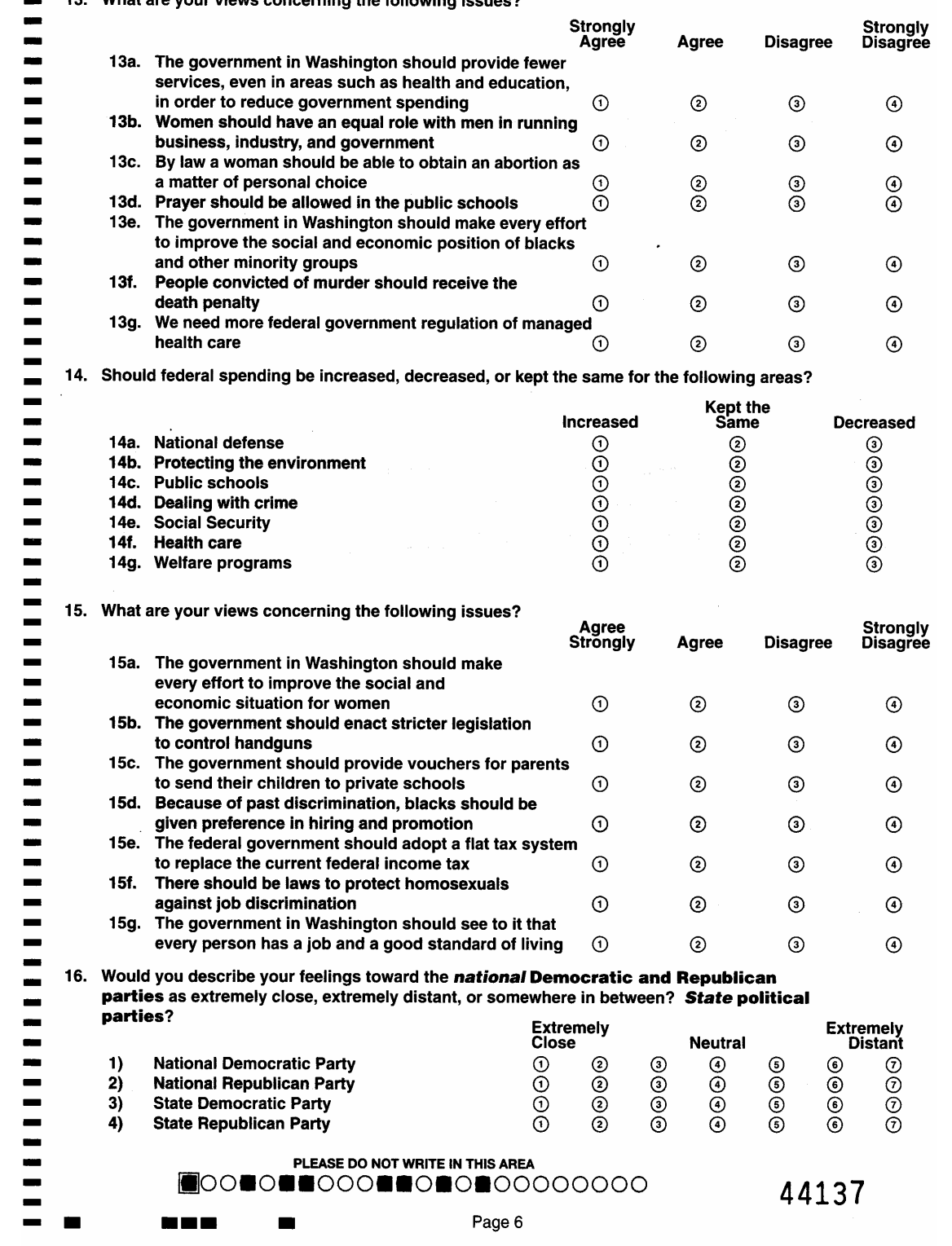


Appendix (continued)

17. There is a lot of speculation these days concerning the current health and future of political parties. In your party and in your county, how does the strength of the party compare to 10 years ago?

\begin{tabular}{|c|c|c|c|c|c|c|}
\hline $010 y$ & years ago? & $\begin{array}{l}\text { Significantly } \\
\text { Stronger }\end{array}$ & $\begin{array}{l}\text { Somewhat } \\
\text { Stronger }\end{array}$ & $\begin{array}{l}\text { Little } \\
\text { Change }\end{array}$ & $\begin{array}{l}\text { Somewhat } \\
\text { Weaker }\end{array}$ & $\begin{array}{l}\text { Significantly } \\
\text { Weaker }\end{array}$ \\
\hline $17 a$. & $\begin{array}{l}\text { The over all county party } \\
\text { organization is }\end{array}$ & (1) & (2) & (3) & (4) & (5) \\
\hline 17b. & $\begin{array}{l}\text { The party's campaign } \\
\text { effectiveness is }\end{array}$ & (1) & (2) & (3) & (4) & (5) \\
\hline 17c. & The party's ability to & & & & & \\
\hline $17 d$. & $\begin{array}{l}\text { raise funds is } \\
\text { The party's role in recruiting }\end{array}$ & (1) & (2) & (3) & (4) & (5) \\
\hline $17 e$. & $\begin{array}{l}\text { candidates for public office is } \\
\text { The party's efforts to develop } \\
\text { the organizational skills of }\end{array}$ & (1) & (2) & (3) & (4) & (5) \\
\hline $\begin{array}{l}17 f . \\
17 g . \\
17 \mathrm{~h} .\end{array}$ & $\begin{array}{l}\text { workers is } \\
\text { The party's use of the media is } \\
\text { The party's use of opinion polls is } \\
\text { The party's use of computer }\end{array}$ & (1) & $\begin{array}{l}\text { (2) } \\
\text { (2) } \\
\text { (2) }\end{array}$ & $\begin{array}{l}\text { (3) } \\
\text { (3) }\end{array}$ & (4) & $\begin{array}{l}\text { (5) } \\
\text { (5) } \\
\text { (5) }\end{array}$ \\
\hline & technology is & (1) & (2) & (3) & (4) & (5) \\
\hline 171. & $\begin{array}{l}\text { The party's strength } \\
\text { among county voters is }\end{array}$ & (1) & (2) & (3) & (4) & (5) \\
\hline
\end{tabular}

18. Political parties often represent people of differing views. How much DISAGREEMENT is there WITHIN your STATE party in each of the following areas?

18a. Between people of different ideological viewpoints
18b. Between supporters of different party leaders
18c. Between long-time residents and newcomers
18d. Between different regions of the state
18e. Between urban and rural areas of the state
18f. On the issue of taxes
18g. On the issue of abortion
18h. On racial issues
18i. On issues of government spending

\begin{tabular}{|c|c|c|c|}
\hline $\begin{array}{l}\text { Great } \\
\text { Deal }\end{array}$ & $\begin{array}{c}\text { Fair } \\
\text { Amount }\end{array}$ & Some & $\begin{array}{l}\text { Very } \\
\text { Little }\end{array}$ \\
\hline (1) & (2) & (3) & (4) \\
\hline (1) & (2) & (3) & (4) \\
\hline (1) & (2) & (3) & (4) \\
\hline (1) & (2) & (3) & (4) \\
\hline (1) & (2) & (3) & (4) \\
\hline (1) & (2) & (3) & (4) \\
\hline (1) & (2) & (3) & (4) \\
\hline (1) & (2) & (3) & (4) \\
\hline (1) & (2) & (3) & (4) \\
\hline
\end{tabular}

19. Would you say the amount of factionalism within your STATE political party is:

(1) Very high

(2) Moderately high

(3) Moderately low

(4) Very low

20. Would you say the amount of factionalism within your COUNTY political party is:

(1) Very high

(2) Moderately high

(3) Moderately low

(4) Very low

21. How active have you been in each of the following groups:

21a. Teacher's organizations
21b. Business or professional organizations
21c. Civic organizations
21d. Labor unions
21e. Church groups
21f. Environmental groups
21g. Civil rights groups
21h. Women's rights groups
21i. Anti-abortion groups
21j. Other group
(Please identify

$\begin{array}{cc}\begin{array}{c}\text { Not Very } \\ \text { Active }\end{array} & \begin{array}{c}\text { Not at al } \\ \text { Active }\end{array} \\ \text { (3) } & \text { (4) } \\ \text { (3) } & 44 \\ \text { (3) } & 4 \\ \text { (3) } & 4 \\ \text { (3) } & 4 \\ \text { (3) } & 4 \\ \text { (3) } & 4 \\ \text { (3) } & 4 \\ \text { (3) } & \text { (4) } \\ \text { (3) } & \text { (4) }\end{array}$


22. Finally, we would like some information about your personal background.

22a. What is your age? ___ years.

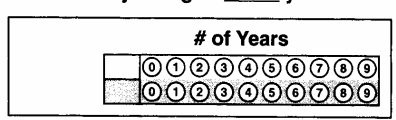

22b. How long have you lived in this state? years.

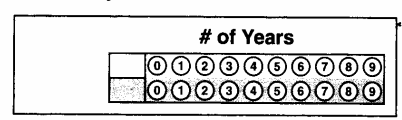

22c. What is your gender?

OMale O Female

22d. What is your racial/ethnic background? Please mark those that apply:

(1) White

(4) Asian American

(2) African American (5) Native American

(3) Hispanic American (6) Other

If "Other",

name

22e. Where did you live for most of the first 18 years of your life?

(1) This state

(2) Another southern state (5) The western U.S.

(3) The eastern U.S.

(6) Another country

22f. What is the highest level of formal education you have completed?

(1) High school or less

(2) Some college

(3) 4 yr college degree

(4) Graduate or professional degree

22g. What is the approximate level of your family's yearly income?

\section{(1) Under $\$ 25,000$ (4) $\$ 75,000-99,999$}

(2) $\$ 25,000-49,999$ (5) $\$ 100,000-150,000$

(3) $\$ \mathbf{5 0 , 0 0 0 - 7 4 , 9 9 9}$

(6) More than $\$ 150,00$
23. What is your religious preference?

(1) Protestant

(2) Roman Catholic

(3) Jewish

(4) Something else

(name)

(5) Nonbeliever

23a. If Protestant, what church or denomination is that (for example, Baptist, Southern Baptist, African Methodist Episcopal, Church of God, etc.). Please write the name below,

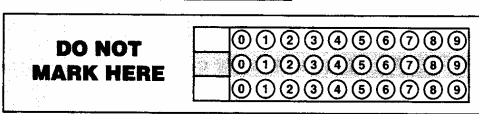

23b. How often do you attend church or synagogue services?

(1) More than once a week

(2) Once a week

(3) Almost every week

(4) Once or twice a month

(5) A few times a year

6) Never

23c. How much guidance would you say that religion plays in your day to-day life?

(1) Great deal

(2) Fair amount

(3) Some

(4) Very little

(5) No guidance

23d. Do you consider yourself to be a "Born-Again" Christian?

OYes ONo

23e. How close do you feel toward Christian Right groups?

(1) Very close

(2) Close

(3) Neutra

(4) Far

(5) Very far

Thank you for your cooperation in answering these questions. All of your answers are STRICTLY CONFIDENTIAL and only will be analyzed in the aggregate for each of the 11 southern states or for the southern region.

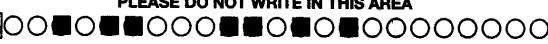

Mark Reflex by NCS MM235781-1 $654321 \quad$ EDO6 Printed in U.S.A. 
18 | John A. Clark and Charles Prysby, Editors

\section{NOTES}

${ }^{1}$ On the region's politics generally, see Black and Black (2002), Bullock and Rozell (2003b), and Lamis (1999). Robert Steed, Laurence Moreland, and Tod Baker have edited a series of volumes on presidential elections in the South; see, most recently, Steed and Moreland (2002).

${ }^{2}$ The study was funded by National Science Foundation Grant SES-9986501 and SES-9986523. Principal investigators were Charles Prysby and John Clark. Any opinions, findings, conclusions or recommendations expressed in these articles are those of the authors and do not necessarily reflect the views of the National Science Foundation.

${ }^{3}$ The original study was funded by National Science Foundation Grant SES9009846 and included information on more than 10,000 activists. The data are available for analysis from the Inter-University Consortium for Political and Social Research (ICPSR). Significant publications from the study include Hadley and Bowman (1995; 1998) and Steed et al. (1998). The following articles all rely on data collected by the Southern Grassroots Party Activists 2001 Project and on data collected by the 1991 SGPA project.

\section{REFERENCES}

Aldrich, John H. 1995. Why Parties? Chicago: University of Chicago Press.

Bibby, John F. 1990. Party Organization at the State Level. In The Parties Respond: Changes in the American Party System, ed. L. Sandy Maisel. Boulder, CO: Westview Press.

Black, Earl, and Merle Black. 1987. Politics and Society in the South. Cambridge, MA: Harvard University Press.

Black, Earl, and Merle Black. 2002. The Rise of Southern Republicans. Cambridge, MA: Harvard University Press.

Bullock, Charles S. III, and Mark J. Rozell. 2003a. Introduction: Southern Politics in the Twenty-first Century. In The New Politics of the Old South, $2 \mathrm{~d}$ ed., eds. Charles S. Bullock, III, and Mark J. Rozell. Lanham, MD: Rowman \& Littlefield.

Bullock, Charles S. III, and Mark J. Rozell, eds. 2003b. The New Politics of the Old South, 2d ed. Lanham, MD: Rowman \& Littlefield.

Cohen, Jeffrey E., Richard Fleisher, and Paul Kantor, eds. 2001. American Political Parties: Decline or Resurgence? Washington, DC: CQ Press.

Coleman, John J. 1996. Party Organizational Strength and Public Support for Parties. American Journal of Political Science 40:805-824.

Cotter, Cornelius P., James L. Gibson, John F. Bibby, and Robert J. Huckshorn. 1984. Party Organizations in American Politics. New York: Praeger.

Frendreis, John P., and Alan R. Gitelson. 1993. Local Political Parties in an Age of Change. American Review of Politics 14:533-547.

Gibson, James L., Cornelius P. Cotter, John F. Bibby, and Robert J. Huckshorn. 1983. Assessing Party Organizational Strength. American Journal of Political Science 27:193-222.

Hadley, Charles D., and Lewis Bowman, eds. 1995. Southern State Party Organizations and Activists. Westport, CT: Praeger. 
Hadley, Charles D., and Lewis Bowman, eds. 1998. Party Activists in Southern Politics: Mirrors and Makers of Change. Knoxville: University of Tennessee Press.

Herrnson, Paul S. 1994. The Revitalization of National Party Organizations. In The Parties Respond: Changes in American Parties and Campaigns, 2d ed., ed. L. Sandy Maisel. Boulder, CO: Westview.

Herrnson, Paul S., and David Menefee-Libey. 1990. The Dynamics of Party Organizational Development. Midsouth Political Science Journal 11:3-30.

Kayden, Xandra, and Eddie Mahe, Jr. 1985. The Party Goes On. New York: Basic Books.

Key, V.O., Jr. 1949. Southern Politics in State and Nation. New York: Alfred A. Knopf.

Klinkner, Philip A. 1994. The Losing Parties: Out-Party National Committees 19561993. New Haven, CT: Yale University Press.

Lamis, Alexander P., ed. 1999. Southern Politics in the 1990s. Baton Rouge: Louisiana State University Press.

Schlesinger, Joseph A. 1985. The New American Political Party. American Political Science Review 79:1152-1169.

Steed, Robert P., John A. Clark, Lewis Bowman, and Charles D. Hadley, eds. 1998. Party Organization and Activism in the American South. Tuscaloosa: The University of Alabama Press.

Steed, Robert P., and Laurence W. Moreland, eds. 2002. The 2000 Presidential Election in the South. Westport, CT: Praeger.

Wekkin, Gary D. 1985. Political Parties and Intergovernmental Relations in 1984: The Consequences of Party Renewal for Territorial Constituencies. Publius 15:19-37. 
